\title{
Pengaruh Kecerdasan Logis-Matematis Terhadap Hasil Belajar Matematika Pada Siswa Kelas VII Di MTSN 2 Padangsidimpuan
}

\author{
Lili Nur Indah Sari* \\ Email: lili@iain-padangsidimpuan.ac.id \\ Fakultas Tarbiyah dan Ilmu Keguruan IAIN Padangsidimpuan
}

\begin{abstract}
The formulation of the problem in this study is whether there is the influence of logical-mathematical intelligence on the learning outcomes of class VII students of Padangsidimpuan MTsN 2? The purpose of this study was to determine the effect of logical-mathematical intelligence on the mathematics learning outcomes of class VII students of Padangsidimpuan 2 MTsN.

This research includes the type of quantitative research using the Ex Post Facto method. The population in this study were VII grade students of MtsN 2 Padangsidimpuan which numbered 211 students while the sample was all students who took the test of Logical-Mathematical Intelligence which amounted to 211 people. The data collection method used is a test with data analysis techniques namely $\mathrm{t}$ test.

The results showed that: There was a significant influence between logical-mathematical intelligence and the mathematics learning outcomes of class VII students of Padangsidimpuan MTsN 2 as evidenced by the results of the t test of 17.137 greater than the $t$ table of 1.98 (17.137> 1.98) which means there are differences in learning outcomes of students who have high logical-mathematical intelligence with students who have low logical-mathematical intelligence. So that it can be concluded that there is a significant influence between LogicalMathematical intelligence variables and mathematics learning outcomes where students who have high logical-mathematical intelligence, the learning outcomes are high and vice versa.
\end{abstract}

Keywords: logical-mathematical intelligence, learning outcomes of mathematics, mathematics, learning outcomes, learning mathematics

* Correspondence:

Email: lili@iain-padangsidimpuan.ac.id 


\begin{abstract}
Abstrak
Rumusan masalah dalam penelitian ini adalah apakah ada pengaruh kecerdasan logis-matematis terhadap hasil belajar siswa kelas VII MTsN 2 Padangsidimpuan? Tujuan penelitian ini adalah untuk mengetahui pengaruh kecerdasan logis-matematis terhadap hasil belajar matematika siswa kelas VII MTsN 2 Padangsidimpuan.

Penelitian ini termasuk jenis penelitian kuantitatif dengan menggunakan metode Ex Post Fakto. Populasi pada penelitian ini adalah siswa kelas VII MtsN 2 Padangsidimpuan yang berjumlah 211 siswa sedangkan sampelnya seluruh siswa yang mengikuti tes kecerdasan Logis-matematis yaitu berjumlah 211 orang. Metode pengumpulan data yang digunakan adalah tes dengan Teknik analisisa data yaitu Uji t.

Hasil penelitian menunjukkan bahwa: Terdapat pengaruh signifikan antara kecerdasan logis-matematika dengan Hasil belajar matematika siswa kelas VII MTsN 2 Padangsidimpuan yang dibuktikan dengan hasil uji t hitung sebesar 17,137 lebih besar dari $t$ tabel sebesar $1,98(17,137>1,98)$ yang berarti ada perbedaan hasil belajar siswa yang memiliki kecerdasan Logis-matematis tinggi dengan siswa yang memiliki kecerdasan Logis -matematis rendah. Sehingga diperoleh kesimpulan ada pengaruh yang signifikan antara variabel kecerdasan Logis-Matematis dengan hasil belajar matematika dimana siswa yang memiliki kecerdasan Logis-matematis tinggi maka hasil belajarnya tinggi dan begitu juga sebaliknya.
\end{abstract}

Kata Kunci: kecerdasan logis-matematis, hasil belajar matematika, matematika, hasil belajar, belajar matematika

\title{
A. PENDAHULUAN
}

Pendidikan adalah usaha sadar dan terencana untuk mewujudkan suasana belajar dan proses pembelajaran agar peserta didik secara aktif mengembangkan potensi dirinya untuk memiliki kekuatan spiritual keagamaan, pengendalian diri, kepribadian, kecerdasan, akhlak mulia, serta keterampilan yang diperlukan dirinya, masyarakat, bangsa, dan negara. ${ }^{1}$ Tujuan pendidikan memuat gambaran tentang nilai-nilai yang baik, luhur, pantas, benar dan indah untuk kehidupan.Karena itu pendidikan memiliki dua fungsi yaitu memberikan arah kepada segenap kegiatan pendidikan dan merupakan sesuatu yang ingin dicapai oleh segenap kegiatan pendidikan. ${ }^{2}$ Ilmu pengetahuan merupakan bekal manusia dalam melangsungkan kehidupannya dimana ilmu pengetahuan berperan sangat penting dan mempunyai andil besar untuk meningkatkan kualitas hidup manusia, dengan modal ilmu pengetahuan dan keterampilan yang diperolehnya melalui proses pendidikan diharapkan mampu mengatasi berbagai problema kehidupannya dimasa yang akan datang.

\footnotetext{
${ }^{1}$ Undang-undang RI nomor 20 tahun 2003, Tentang Sistem Pendidikan Nasional 2003 (Jakarta: Redaksi Sinar Grafika, 2009), hlm. 3.

${ }^{2}$ Umar Tirtarahardja, Pengantar Pendidikan (Jakarta: PT Rineka Cipta, 2005), hlm. 37.
} 
Sebagai suatu komponen dari pendidikan, tujuan pendidikan memegang posisi penting diantara komponen-komponen pendidikan lainnya. Hal ini dikarenakan setiap komponen-komponen pendidikan lainnya dilaksanakan mengarah kepada untuk mencapai pendidikan.Ketika kegiatan-kegiatan yang dilakukan dalam pendidikan tidak relevan dengan tujuan pendidikan maka dapat dikatakan sebagai sesuatu yang menyimpang, tidak fungsional, bahkan dapat dianggap salah sehingga dicegah agar tidak terjadi.

Matematika tumbuh dan berkembang karena proses berfikir, oleh karena itu logika adalah dasar untuk terbentuknya matematika. ${ }^{3}$ Dalam dunia pendidikan, matematika merupakan salah satu mata pelajaran yang memiliki posisi tersendiri dan mendapat perhatian yang begitu besar. Perhatian ini tidak hanya pada kalangan pendidik bahkan para peneliti pendidikan matematika. Hal ini dikarenakan banyaknya aplikasi dalam kehidupan sehari-hari seperti sains, perdagangan dan industri yang berkaitan dengan matematika karena matematika merupakan alat komunikasi yang singkat dan tidak ambigius serta berfungsi sebagai alat untuk mendeskripsikan dan memprediksi. ${ }^{4}$ Hampir semua ilmu pengetahuan dan teknologi memerlukan matematika. Dengan peran ilmu matematika yang sangat besar ini, menuntut setiap orang untuk dapat menguasai matematika.

Dengan kemampuan berfikir tersebut, manusia mampu memecahkan permasalahan hidup yang dihadapinya dari yang sederhana sampai yang kompleks. Namun seberapa besar kemampuan masing-masing individu dalam menghadapimasalah tergantung seberapa besar tingkat kecerdasan yang dimiliki individu itu sendiri. Semakin tinggi tingkat kecerdasan seseorang, akan semakin mudah baginya dalam menyelesaikan suatu masalah yang sama dibanding orang lain yang mempunyai tingkat kecerdasan lebih rendah. Akan tetapi, hal ini juga sangat tergantung dari jenis masalah dan kecerdasan mana yang dipakai untuk menyelesaikan masalah tersebut. Hal ini menunjukkan adanya berbagai macam kecerdasan dalam diri manusia.

Berbagai macam tipe kecerdasan manusia tersebut, diungkapkan oleh Howard Gardner dalam teorinya multiple intelligence (kecerdasan majemuk) yang dikutip oleh Hamzah B.Uno dan Masri Kuadrat yang menyatakan bahwa kecerdasan majemuk ini terdiri dari kecerdasan bahasa, kecerdasan logis matematis, kecerdasan spasial, kecerdasan kinestetik jasmani, kecerdasan musikal, kecerdasan interpersonal, kecerdasan intrapersonal dan kecerdasan naturalis. ${ }^{5}$ Kecerdasan ini baik secara langsung maupun tidak langsung akan mempengaruhi hasil belajar siswa. Hal ini juga didukung oleh pendapat Slameto yang mengatakan, 'inteligensi akan mempengaruhi kemajuan belajar. ${ }^{6}$

Siswa yang memiliki kecerdasan matematis-logis yang tinggi cenderung menyenangi kegiatan menganalisis dan mempelajari sebab akibat terjadinya sesuatu. ${ }^{7}$ Dengan demikian siswa dengan mudah memahami suatu masalah dan

\footnotetext{
${ }^{3}$ Herman Suherman, Strategi Matematika Kontenporer (Bandung: JICA, 2010), hlm. 3.

${ }^{4}$ Hamzah B. Uno dan Masri Kuadrat, Mengelola Kecerdasan dalam Pembelajaran: Sebuah Konsep Pembelajaran Berbasis Kecerdasan (Jakarta: PT Bumi Aksara, 2009), hlm. 108.

${ }^{5}$ Ibid.,hlm. 11.

${ }^{6}$ Slameto, Belajar dan Faktor-faktor yang Mempengaruhinya (Jakarta: PT Rineka Cipta, 2010), hlm. 56.

${ }^{7}$ Hamzah B. Uno dan Masri Kuadrat, Op.Cit.,hlm. 11.
} 
menganalisa serta menyelesaikannya dengan tepat. Hal ini peneliti peroleh berdasarkan hasil penelitian karya ilmiah yang relevan dan diperoleh hasilnya bahwa dalam kegiatan belajar matematika, siswa yang memiliki kecerdasan matematis-logis tinggi maka hasil belajarnya pun tinggi. Namun pada kenyataannya di lapangan, berdasarkan wawancara dengan beberapa siswa SMP pada umumnya memvonis matematika sebagai bidang studi yang sulit dan memerlukan kecerdasan yang tinggi dalam mempelajari matematika. Hal ini ditunjukkan dengan kemampuan dalam berhitung dan logikanya masih kurang baik. Hal ini terlihat ketika siswa diberikan soal-soal cerita yang perlu dianalisis terlebih dahulu. Mereka tidak dapat menjawab soal-soal tersebut dikarenakan mereka tidak dapat mengidentifikasi masalah-masalah dalam soal tersebut.

Selain masalah umum yang telah dipaparkan di atas, berdasarkan studi pendahuluan yang peneliti laksanakan di Madrasah Tsanawiyah Negeri (MTsN) 2 Padangsidimpuan berdasarkan wawancara dengan seorang guru matematika dengan Ibu Evi kelas VII yang menjelaskan bahwasanya rendahnya hasil belajar matematika didominasi dengan soal-soal yang berkaitan dengan ketepatan dalam perhitungan, terlebih soal-soal yang mengandung angka-angka dengan operasi campuran serta angka-angka yang mengandung unsur negatif, disini siswa masih bingung mana yang terlebih dahulu dikerjakan, hal ini membuat siswa sering keliru sehingga membuat penyelesaiannya bernilai salah, selain itu kemampuan dalam menganalisa soal yang berbentuk cerita membuat siswa kesulitan dalam memahami maksud dari soal tersebut sehingga bukan hanya penyelesaian bahkan membuat model matematika siswa tidak mampu. ${ }^{8}$

Menurut salah satu siswa dari MTsN 2 Padangsidimpuan kelas VII bahwa pembelajaran matematika membutuhkan ketelitian yang tinggi terlebih memahami soal-soal yang berbentuk cerita, belum lagi menjawabnya terkadang soalnya sulit dimengerti arahannya seperti membuat soal tersebut kedalam bentuk simbolsimbol matematika. Hal ini yang membuat siswa jenuh untuk mengerjakan soalsoal yang perlu analisis.Sehingga terkadang banyak siswa yang menyepelekan pembelajaran ini. ${ }^{9} \mathrm{Hal}$ ini berhubungan dengan kecerdasan yang dimiliki oleh setiap siswa yang erat hubungannya dengan kecerdasan logis-matematis.Karena permasalahan tersebut terkait dengan kemampuan dalam kcerdasan logismatematis.Untuk itu seorang guru perlu mengetahui kecerdasan yang dimiliki siswa yang diharapkan nantinya guru dapat mengembangkan dan melatih kecerdasan tersebut dalam rangka memudahkan dalam mempelajari materi.

Berpijak pada uraian di atas bahwa setiap individu dilahirkan telah memiliki potensi yang genius dan tidak ada anak yang bodoh, karena setiap anak dilahirkan dengan kemampuannya masing-masing, yang ada anak yang menonjol pada satu atau beberapa jenis kecerdasan termasuk memiliki potensi kecerdasan matematis. Tinggal bagaimana kita sebagai guru, orang tua, pendamping dalam mengembangkan kecerdasan tersebut sejak usia dini dengan harapan ketika mereka dewasa tidak ada lagi kesulitan dalam mencari kecerdasan matematisnya selain itu diharapkan ketika telah berada dijenjang yang lebih tinggi tidak merasa kesulitan dalam menerima materi pelajaran matematika.

8 Ibu Evi, Guru Matematika di MTsN 2 Padangsidimpuan, Wawancara di Padangsidimpuan, tanggal 23 November 2017 jam 09.30-10.00.

${ }^{9}$ Taufik Hidayat, siswa MTsN 2 Padangsidimpuan, Wawanacara di Sihitang, Tanggal 22 November 2017 jam 18.00-18.30. 
Jika kecerdasan logis-matematis tersebut dikaitkan dengan hasil belajar matematika siswa di sekolah tentunya dapat diidentifikasikan bahwa hal tersebut ada pengaruhnya.Namun, ada dan tidaknya pengaruh kecerdasan logis-matematis terhadap hasil belajar matematika siswa perlu adanya penelitian lebih lanjut. Hal ini disebabkan karena banyaknya faktor yang mempengaruhi hasil belajar, dan inteligensi/kecerdasan adalah salah satu faktor diantara faktor-faktor lain.

\section{Kecerdasan Logis-Matematis}

Kecerdasan Logis-matematis adalah salah satu dari delapan jenis kecerdasan jamak yang dimiliki manusia seperti dikemukakan oleh Howard Gardner seorang psikolog dari Project Zero di Harvard University tahun $1983 .{ }^{10}$ Menurut Gardner yang dikutip oleh John W. Santrock, dalam buku "Perkembangan Anak", setiap orang memiliki semua tipe kecerdasan, tetapi dalam tingkatan yang bervariasi. Sebagai bukti bahwa dalam diri manusia tersebut terdapat kecerdasan ganda yaitu dengan contoh ia mendeskripsikan bahwa orang yang terampil dalam suatu bidang, misalnya komposisi musik namun tidak pandai dalam bidang matematika dan bahasa inggris. ${ }^{11} \mathrm{Hal}$ ini disebabkan berdasarkan hasil penelitian bahwa kecerdasan ganda sudah terdapat dalam diri masing-masing orang, namun karena tidak terasah sejak kecil sehingga tidak semua jenis kecerdasan ganda dapat berkembang secara optimal. ${ }^{12}$

Menurut teori multiple intelligence, dalam diri manusia ada delapan kecerdasan majemuk. Kecerdasan majemuk ini patut diperhitungkan karena memberikan pengaruh bagi manusia dalam proses mendapatkan pengetahuan. Namun pada penelitian ini akan mengambil salah satu dari delapan kecerdasan majemuk yang tersebut di atas yang akan dijadikan variabel dalam penelitian, yaitu kecerdasan logis matematis dan pengaruhnya terhadap hasil belajar matematika. Kecerdasan logis matematis menuntut seseorang berfikir secara logis, linier, teratur, mampu berhitung serta menalar. ${ }^{13}$ Berbagai penelitian terhadap otak memperlihatkan bahwa belahan kiri merupakan tempat proses logika, keteraturan, rasional, dan verbal. Kecerdasan ini sering menitikberatkan otak bagian kiri. Karena cara kerjanya yang melibatkan otak kiri, maka kecerdasan ini dianggap penting dalam pembelajaran matematika. ${ }^{14}$

Secara teoretis, kecerdasan logis matematis sebagai salah satu dari kecerdasan majemuk (multiple intellegence) bisa didefinisikan sebagai kapasitas seseorang untuk berpikir secara logis dalam memecahkan kasus atau permasalahan dan melakukan perhitungan matematis.Orang dengan kecerdasan logis matematis mempunyai kemampuan mengelola logika dan angka dengan aktivitas utama berpikir logis, berhitung, menyusun pola hubungan serta memecahkan masalah. ${ }^{15}$

${ }^{10}$ Munif Chatib, Gurunya Manusia (Bandung: Kaifa, 2014), hlm. 132.

${ }^{11}$ John W. Santrock, Perkembangan Anak (Indonesia: Erlangga, 2007), hlm. 322.

12 Hamzah B. Uno dan Masri Kuadrat, Mengelola Kecerdasan dalam Pembelajaran: Sebuah Konsep Pembelajaran Berbasis Kecerdasan (Jakarta: PT Bumi Aksara, 2009), hlm. 37.

${ }^{13}$ Nini Subini, Mengatasi Kesulitan Belajar Pada Anak (Jogjakarta: Javalitera, 2011), hlm. 73.

${ }^{14}$ Hamzah B. Uno dan Masri Kuadrat, Op.Cit.,hlm. 46.

15 Trisna Jayantika, dkk. "Kontribusi bakat numerik, kecerdasan spasial, dan kecerdasan logis matematis terhadap prestasi belajar matematika siswa SD Negeri di Kabupaten Buleleng"dalam 
Menurut Mohammad Reza Noruzi "Logical-mathematical adalahKapasitas untuk menggunakan angka-angka secara efektif (misal sebagai ahli matematik, mengenakan pajak akuntan, atau orang statistik) dan untuk memberi alasan dengan baik (misal sebagai ilmuwan, programmer komputer, atau ahli logika). Proses menggunakan logical-mathematical kecerdasan/inteligensi meliputi penggolongan, kesimpulan, pengamatan, kalkulasi, dan pengujian hipotesis. ${ }^{16}$

Menurut Hamzah B.Uno dalam bukunya "Kecerdasan logis-matematis adalah kemampuan seseorang dalam berfikir secara induktif dan deduktif, berfikir menurut aturan logika, memahami dan menganalisis pola angka-angka, serta memecahkan masalah dengan menggunakan kemampuan berfikir. ${ }^{17}$

Berdasarkan uraian di atas, dapat disimpulkan bahwa kecerdasan logismatematis adalah kemampuan seseorang dalam menghitung, mengukur, menggunakan angka-angka, memecahkan soal-soal matematis, berfikir secara induktif dan deduktif, serta membuat pola-pola dan hubungan-hubungan yang logis dalam kehidupan sehari-hari.

Beberapa ciri-ciri kecerdasan logis matematis yang menonjol yaitu: (1) Mampu mengolah angka; (2) mampu berfikir berdasar logika; (3) menyukai keteraturan; (4) menyukai pola hubungan tertentu; (5) mampu berhitung menalar; (6) mampu memecahkan masalah secara rasional; $(7)$ berpikir secara matematis. ${ }^{18}$

\section{Pengaruh Kecerdasan Logis-Matematis terhadap Hasil Belajar Matematika}

Sekarang ini pendidikan sangatlah penting bagi kita semua. Karena semakin maju zaman akan semakin maju pula tingkat pendidikan yang harus kita capai. Pendidikan merupakan kunci bagi suatu bangsa untuk meningkatkan kualitas sumberdaya manusia dan sekaligus kualitas bangsanya.Hasil belajar merupakan tolak ukur dari suatu pendidikan. Pendidikan dikatakan berhasil apabila individu atau siswa memperoleh hasil belajar yang baik, begitu pula apabila hasil belajar siswa rendah maka dapat dikatakan bahwa proses pendidikan yang dilakukan belum berhasil.

Kecerdasan atau inteligensi besar peranannya dalam menentukan berhasil dan tidaknya seseorang mempelajari atau mengikuti suatu program pendidikan. Orang yang lebih cerdas pada umumnya akan lebih mampu belajar daripada orang yang kurang cerdas. Pada dasarnya setiap anak memiliki kecerdasan yang berbeda-beda satu sama lain. Salah satu kecerdasan yang pasti dimiliki oleh setiap anak adalah kecerdasan logis-matematis.Akan tetapi, tingkat kecerdasannya berbeda-beda karena perkembangannya tergantung oleh kondisi-kondisi anak.

Journal Program Pascasarjana Universitas Pendidikan Ganesha Program Studi Matematika, Volume 2, tahun 2013, hlm. 4.

${ }^{16}$ Mohammad Reza Noruzi, “The Enigma of Howard Gardner's Multiple Intelligences Theory in the Area of Organizational Effectiveness", International Journal of Business and Management, Vol. 5, No. 5, May 2010, hlm. 2.

${ }^{17}$ Hamzah B. Uno dan Masri Kuadrat, Op.Cit., hlm. 11.

${ }^{18}$ Eka Zahrotun Ni'mah, “ Pengaruh Kecerdasan Logis Matematis dan Motivasi Terhadap Hasil Belajar Matematika Siswa Kelas VII MTsN Langkapan” (Skripsi, IAIN Tulungagung, 2015), hlm. 21. 
Kecerdasan logis-matematis merupakan kemampuan untuk menggunakan angka dengan baik dan penalaran dengan benar. Siswa dengan kecerdasan logismatematis yang tinggi cenderung :

1) Menyenangi kegiatan menganalisis dan mempelajari sebab-akibat terjadinya sesuatu.

2) Menyenangi berfikir secara konseptual, yaitu misalnya menyusun hipotesis, mengadakan kategorisasi dan klasifikasi terhadap apa yang dihadapinya.

3) Menyukai aktivitas berhitung dan memiliki kecepatan tinggi dalam menyelesaikan problem matematika.

4) Apabila kurang memahami, mereka akan cenderung berusaha untuk bertanya dan mencari jawaban atas hal yang kurang dipahami tersebut. ${ }^{19}$

\section{Hasil Belajar Matematika}

Hasil belajar dapat dijelaskan dengan memahami dua kata yang membentuknya, " yaitu hasil " dan " belajar ". Pengertian hasil (product) menunjuk pada suatu perolehan akibat dilakukannya suatu aktivitas atau proses yang mengakibatkan berubahnya input secara fungsional. Hasil produksi adalah perolehan yang didapatkan karena adanya kegiatan mengubah bahan (raw material) menjadi barang jadi (finished goods). ${ }^{20}$ Hasil belajar merupakan pencapaian tujuan pendidikan pada siswa yang mengikuti proses belajar mengajar yang artinya hasil belajar itu merupakan realisasi tercapainya tujuan pendidikan. ${ }^{21}$

Belajar merupakan suatu proses usaha yang dilakukan seseorang untuk memperoleh suatu perubahan tingkah laku sebagai hasil pengalaman sendiri dan interaksinya lingkungannya. Perubahan yang terjadi dari diri seseorang banyak sekali baik sifat maupun jenisnya karena itu sudah tentu tidak setiap perubahan dalam diri seseorang merupakan perubahan dalam arti belajar dimana perubahan yang terjadi dalam aspek-aspek kematangan, pertumbuhan dan perkembangan tidak termasuk perubahan dalam pengertian belajar. ${ }^{22}$ Menurut james $\mathrm{O}$. Whittaker, belajar dapat di defenisikan sebagai proses dimana tingkah laku ditimbulkan atau diubah melalui latihan atau pengalaman. ${ }^{23}$

Selain itu menurut Morgan yang dikutip oleh Ngalim Purwanto mengemukakan belajar adalah setiap perubahan tingkah laku yang relatif menetap sebagai suatu hasil dari latihan dan pengalaman. ${ }^{24}$ Dari beberapa definisi yang dikemukakan mengenai belajar di atas maka dapat disimpulkan bahwa belajar adalah proses perubahan perubahan tingkah laku, pemikiran dan pandangan seseorang menuju hal yang baik atau lebih positif.

Sedangkan hasil belajar adalah kemampuan yang diperoleh anak setelah melalui kegiatan belajar. Setiap proses belajar yang dilaksanakan oleh peserta

\footnotetext{
${ }^{19}$ Hamzah B. Uno dan Masri Kuadrat,Op.Cit.,, hlm. 11-12.

${ }^{20}$ Purwanto, Evaluasi Hasil Belajar (Yogyakarta: Pustaka Belajar, 2009), hlm. 44.

${ }^{21}$ Ibid., hlm. 46.

${ }^{22}$ Slameto, Belajar dan Faktor-Faktor yang Mempengaruhinya (Jakarta: Rineka Cipta, 2010), hlm. 2.

${ }^{23}$ Abu Ahmadi dan Widodo Supriyono, Psikologi Belajar (Jakarta: PT Rineka Cipta, 2013), hlm. 126.

${ }^{24}$ Ngalim Purwonto, Psikologi Pendidikan (Bandung: PT Remaja Rosdakarya, 2000), hlm. 84 .
} 
didik akan menghasilkan hasil belajar. Disisi guru, tindak mengajar diakhiri dengan proses evaluasi hasil belajar. Dari sisi siswa hasil belajar merupakan akhirnya pengajaran dari puncak proses belajar. ${ }^{25}$

Mulyono mengutip pendapat keller yang mengatakan bahwa "hasil belajar adalah prestasi aktual yang ditampilkan oleh anak tergantung besarnya usaha yang dilakukan oleh anak. Hasil belajar dipengaruhi juga oleh inteligensi dan penguasaan awal anak tentang materi yang akan dipelajari. ini berarti guru perlu menetapkan tujuan belajar sesuai dengan inteligensi anak, dan pencapaian tujuan belajar perlu menggunakan bahan apersepsi yaitu bahan yang telah dikuasai anak sebagai batu loncatan untuk menguasai bahan pelajaran yang baru. Selain itu hasil belajar juga dipengaruhi oleh adanya kesempatan yang diberikan kepada anak. ${ }^{26}$

Menurut Nana Syaodih Sukmadinata "Hasil belajar merupakan realisasi atau pemekaran dari kecakapan-kecakapan potensial atau kapasitas yang dimiliki seseorang. Penguasaan hasil belajar oleh seseorang dilihat dari prilakunya baik prilaku dalam bentuk penguasaan pengetahuan, keterampilan berfikir maupun keterampilan motoriknya. Di sekolah hasil belajar dilihat dari penguasaan siswa akan mata pelajaran yang ditempuhnya. Hasil belajar tersebut dilambangkan dengan angka-angka atau huruf. ${ }^{27}$

Nana Sudjana dalam bukunya mengemukakan "Hasil belajar adalah kemampuan-kemampuan yang dimiliki siswa setelah ia menerima pengalaman belajarnya. ${ }^{28}$ Kemampuan belajar dari siswa merupakan produk akhir dari suatu proses belajar mengajar. Oleh karena itu dalam kemampuan hasil belajar terdapat klasifikasi penilaian untuk mencapai target hasil belajar siswa.

Matematika adalah suatu aktivitas mental untuk memahami arti dan hubungan-hubungan serta simbol-simbol kemudian diterapkan pada situasi nyata. Menurut schonfeld yang dikutip dari Hamzah B. Uno mendefenisikan bahwa belajar matematika berkaitan dengan apa dan bagaimana menggunakannya dalam membuat keputusan untuk memcahkan masalah. Matematika melibatkan pengamatan, penyelidikan, dan keterkaitannya dengan fenomena fisik dan sosial. ${ }^{29}$

Matematika adalah sebagai suatu bidang ilmu yang merupakan alat pikir, berkomunikasi, alat untuk memecahkan berbagai persoalan praktis, yang unsurunsurnya logika dan intuisi, analisis dan kontruksi, generalitas dan individualitas serta mempunyai cabang-cabang antara lain aritmatika, aljabar, geometri, dan analisis.Belajar matematika didasarkan pada pandangan konstruktivisme, yakni anak belajar matematika dihadapkan pada masalah tertentu berdasarkan pengetahuan yang diperolehnya ketika belajar dan berusaha memecahkannya. ${ }^{30}$

Berdasarkan uraian di atas, dapat disimpulkan bahwa hasil belajar matematika merupakan kemampuan yang diperoleh seseorang melalui kegiatan

\footnotetext{
hlm. 27-28.

${ }^{26}$ Mulyono Abdurrahman, Anak Berkesulitan Belajar (Jakarta: PT Rineka Cipta, 2012),

${ }^{27}$ Nana Syaodih Sukmadinata, Landasan Psikologi Proses Pendidikan (Bandung: Ramaja Rosdakarya, 2004), hlm. 102-103.

28 Nana Sudjana, Penilaian Hasil Proses Belajar Mengajar (Bandung: PT Remaja Rosdakarya, 2001), hlm. 22.

${ }^{29}$ Hamzah B. Uno, Model Pembelajaran (Jakarta: Bumi Aksara, 2008), hlm. 130.

${ }^{30}$ Hamzah B. Uno dan Masri Kuadrat, Op.Cit., hlm. 109.
} 2011), hlm. 34

${ }^{25}$ Moh. Uzer Usman, Menjadi Guru Professional (Bandung: PT Remaja Rosdakarya, 
belajar matematika.Hasil belajar matematika tersebut diukur untuk mengetahui pencapaian tujuan pendidikan sehingga hasil belajar matematika harus sesuai dengan tujuan pendidikan.Pengukuran dilakukan agar pengambilan keputusan hasil belajar matematika dapat diambil secara akurat.Hasil belajar ini biasanya berbentuk angka, huruf, dan kata-kata yang mana bentuk mentahnya terwujud dalam lembaran jawaban ulangan atau ujian yang berguna untuk alat evaluasi bagi guru.Sedangkan bagi siswa menjadi gambaran bagaimana pengetahuannya, kemampuannya dan untuk bahan perbaikan kedepan.

\section{B. METODOLOGI}

Lokasi penelitian dilaksanakan di MTsN 2 Padangsidimpuan di jalan H.T. Rizal Nurdin Km. 6,5 Gg. PendidikanKecamatan Padangsidimpuan, Kota Padangsidimpuan. Penelitian ini dimulai pada bulan januari 2018 sampai dengan Maret 2018.Adapun lokasi penelitian dipilih berdasarkan pertimbangan data yang tersedia dan juga waktu yang dimiliki oleh peneliti.

Jenis penelitian yang digunakan adalah penelitian kuantitatif yang menggunakan metode Ex Post Facto. Populasi dalam penelitian ini adalah seluruh kelas VII MTsN 2 Padangsidimpuan yang terdiri dari 215 siswa. Dengan demikian yang menjadi sampel adalah seluruh siswa MTsN 2 kelas VII yang telah mengikuti tes kecerdasan logis-matematis.

\section{HASIL PENELITIAN DAN PEMBAHASAN}

Tingkat Kecerdasan Logis-Matematis MTsN 2 Padangsidimpuan

\section{Tabel 1}

Deskripsi Data Kecerdasan Logis-Matematis

\begin{tabular}{|l|l|c|}
\hline No & \multicolumn{1}{|c|}{ Statistik } & Variabel \\
\hline 1 & Skor Terendah & 4 \\
\hline 2 & Skor Tertinggi & 17 \\
\hline 3 & Median & 12 \\
\hline 4 & Mean & 11,95 \\
\hline 5 & Standar Deviasi & 2,49 \\
\hline 6 & Modus & 11 \\
\hline
\end{tabular}

Berdasarkan hasil tes yang terdiri dari 18 butir soal yang diberikan kepada responden (sampel penelitian), maka nilai kecerdasan logis-matematis diperoleh nilai tertinggi yaitu 17 dan nilai terendah yaitu 4. Kemudian nilai mean sebesar 11,95 artinya skor tingkat pencapaian nilai tersebut merupakan kategori cukup baik, nilai median sebesar 12 artinya skor tingkat pencapaian nilai tersebut maka nilai tengah dari kecerdasan Logis-matematis merupakan ketegori cukup baik dan nilai modus sebesar 11 sesuai skor tingkat pencapaian nilai tersebut maka nilai yang sering muncul pada tes kecerdasan logis-matematis merupakan kategori cukup baik. Sedangkan standar deviasi sebesar 2,49 yang artinya gambaran menyeluruh penyebaran nilai kecerdasan logis-matematis sebesar 2,49. Hasil pengelompokan skor jawaban responden dapat dilihat pada tabel di bawah ini : 
Tabel 2

Interval Nilai (X) dan Rata-rata (Mean) Nilai Hasil Tes Kecerdasan Logis Matematis Siswa

\begin{tabular}{|c|c|c|c|c|c|}
\hline No & INTERVAL & $\mathbf{F}$ & $\mathbf{X}$ & FX & MEAN \\
\hline 1 & $17-18$ & 1 & 17,5 & 17,5 & \multirow{10}{*}{11,954} \\
\hline 2 & $15-16$ & 38 & 15,5 & 589 & \\
\hline 3 & $13-14$ & 50 & 13,5 & 675 & \\
\hline 4 & $11-12$ & 63 & 11,5 & 724,5 & \\
\hline 5 & $9-10$ & 41 & 9,5 & 389,5 & \\
\hline 6 & $7-8$ & 15 & 7,5 & 112,5 & \\
\hline 7 & $5-6$ & 2 & 5,5 & 11 & \\
\hline 8 & $3-4$ & 1 & 3,5 & 3,5 & \\
\hline 9 & $1-2$ & 0 & 1,5 & 0 & \\
\hline & JUMLAH & 211 & & $100 \%$ & \\
\hline
\end{tabular}

Berdasarkan tabel di atas, distribusi frekuensi skor kecerdasan logisMatematis belajar matematika dapat digambarkan dalam bentuk grafik histogram di bawah ini

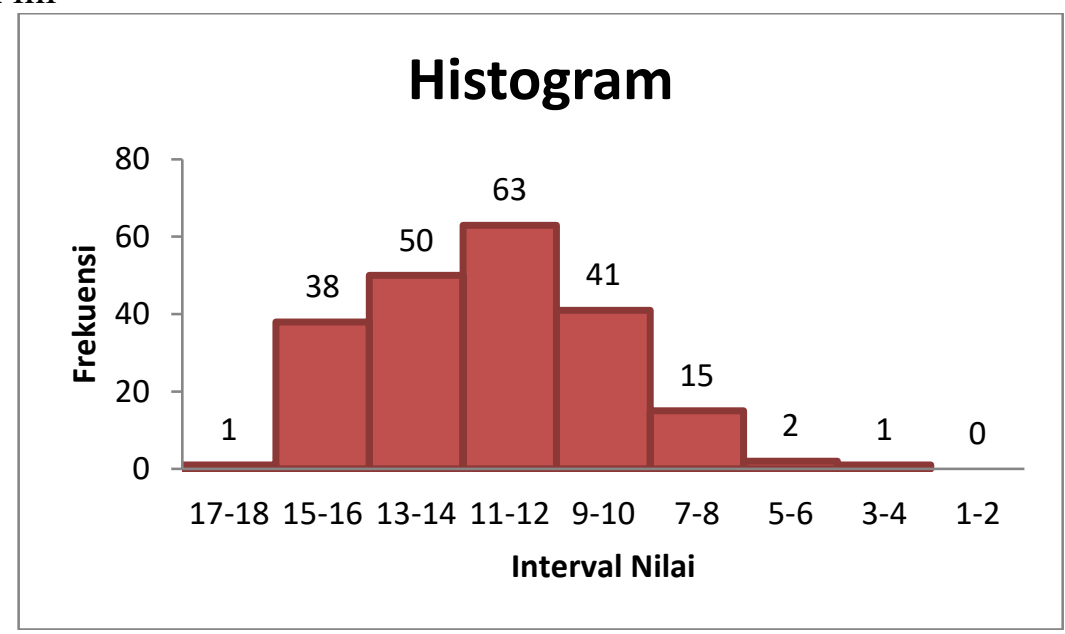

\section{Gambar 1 Histogram kecerdasan Logis-Matematis}

Berdasarkan histogram di atas, distribusi frekuensi skor kecerdasan logismatematika di atas menunjukkan bahwa kelompok yang mempunyai frekuensi terbanyak berada pada interval 11-12 sedangkan frekuensi terendah terletak pada interval 17-18.

Distribusi frekuensi tingkat kecerdasan logika-matematika siswa dapat dilihat pada tabel di bawah ini.

Tabel 3

Kualitas Tingkat Kecerdasan Logis-matematis

\begin{tabular}{|l|l|l|l|}
\hline $\begin{array}{l}\text { Distribusi Skor Kecerdasan } \\
\text { Logika-Matematika }\end{array}$ & Frekuensi & Persentase & Kategori \\
\hline$>14$ & 39 & $18,48 \%$ & Tinggi \\
\hline $9-14$ & 154 & $73 \%$ & Sedang \\
\hline$<9$ & 18 & $8,53 \%$ & Rendah \\
\hline Jumlah & 211 & $100 \%$ & \\
\hline
\end{tabular}




\section{Data Hasil Belajar Matematika Siswa}

Data tentang hasil belajar matematika siswa diambil dari hasil ujian matematika semester ganjil.Hasil ujian semester ganjil yang telah diambil yaitu siswa yang telah mengikuti tes kecerdasan logis-matematis. Untuk selengkapnya nilai hasil belajar matematika siswa dari responden yang berjumlah 211 siswa dapat dilihat dalam lampiran 10. Sedangkan kualifikasi dan interval nilai dapat disajikan sebagai berikut:

Tabel 4

Deskripsi data hasil belajar matematika

\begin{tabular}{|l|l|c|}
\hline No & \multicolumn{1}{|c|}{ Statistik } & Variabel \\
\hline 1 & Skor terendah & 80 \\
\hline 2 & Skor tertinggi & 92 \\
\hline 3 & Median & 82 \\
\hline 4 & Mean & 82,41 \\
\hline 5 & Standar deviasi & 2,57 \\
\hline 6 & Modus & 80 \\
\hline
\end{tabular}

Tabel 5

Interval Nilai (Y) dan Rata-rata (Mean) Hasil Belajar Matematika Siswa

\begin{tabular}{|c|c|c|c|c|c|}
\hline$\overline{\text { No }}$ & Interval Nilai & $\mathrm{F}$ & $\mathrm{X}$ & FX & MEAN \\
\hline 1 & $93-94$ & 0 & 93.5 & 0 & \multirow{8}{*}{82,41} \\
\hline 2 & $91-92$ & 2 & 91,5 & 183 & \\
\hline 3 & $89-90$ & 5 & 89,5 & 447,5 & \\
\hline 4 & $87-88$ & 8 & 87,5 & 700 & \\
\hline 5 & $85-86$ & 29 & 85,5 & 2479,5 & \\
\hline 6 & $83-84$ & 49 & 83,5 & 4091,5 & \\
\hline 7 & $81-82$ & 54 & 81,5 & 4401 & \\
\hline 8 & $79-80$ & 64 & 79,5 & 5088 & \\
\hline & JUMLAH & 211 & & & \\
\hline
\end{tabular}

Berdasarkan tabel di atas, distribusi frekuensi hasil belajar matematika dapat digambarkan dalam bentuk grafik histogram di bawah ini:

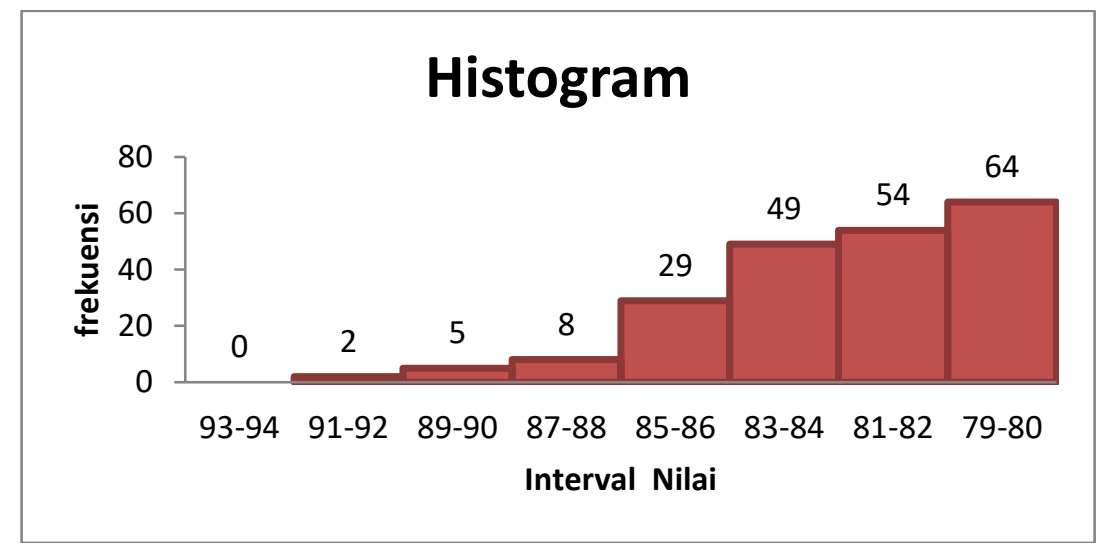

Gambar 2

Histogram Hasil belajar Matematika 
Distribusi frekuensi tingkat hasil belajar matematika siswa dapat dilihat pada tabel di bawah ini.

Tabel 14

Kualitas Hasil Belajar Matematika Siswa

\begin{tabular}{|c|l|c|c|}
\hline Rata-rata & Interval nilai & kualitas & Kriteri \\
\hline \multirow{3}{*}{82,16} & $>84,99$ & Tinggi & \multirow{2}{*}{ Sedang } \\
\cline { 2 - 3 } & $79,84-84,98$ & Sedang & \\
\cline { 2 - 3 } & $<79,84$ & Rendah & \\
\hline Jumlah & 211 & & \\
\hline
\end{tabular}

Distribusi frekuensi kualitas hasil belajar matematika siswa dapat dilihat pada histogram di bawah ini :

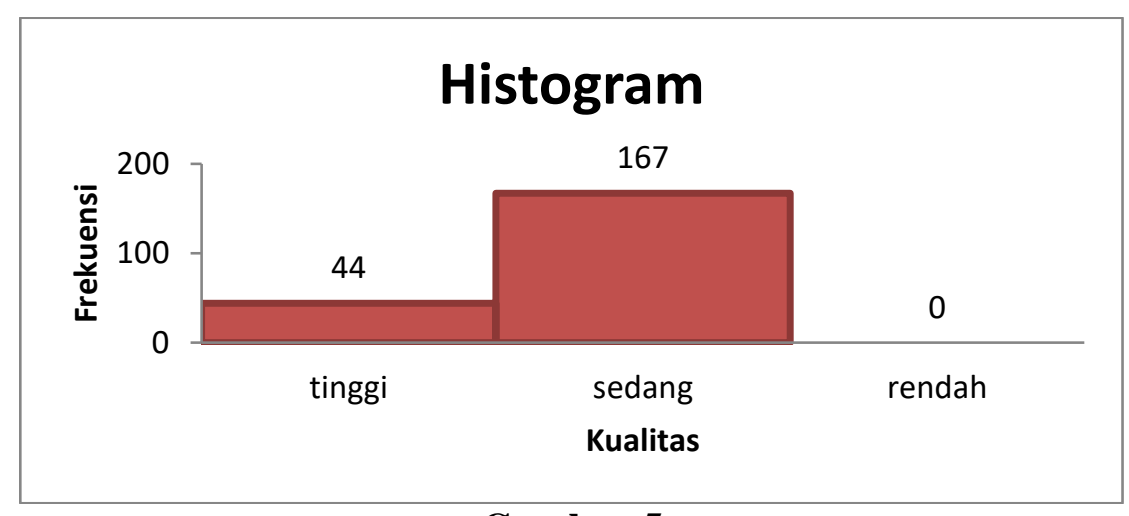

Gambar 5

Histogram Hasil Belajar Matematika

Dari uraian di atas diketahui bahwa hasil belajar matematika siswa MTsN 2 Padangsidimpuan kelas VII termasuk dalam kategori sedang yaitu berada di antara nilai 79,84- 84,98 dengan nilai rata-rata 82,41.

\section{Pembahasan}

Dari hasil analisis di atas dapat dikemukakan bahwa hipotesis dalam penelitian ini yaitu "ada pengaruh yang positif dan signifikan kecerdasan logismatematis terhadap hasil belajar matematika siswa MTsN 2 Padangsidimpuandi tunjukkan dengan $\mathrm{t}$ hitung $>\mathrm{t}$ tabel $(17,137>1.98)$ dengan taraf signifikan (a) $5 \%$. Sehingga dapat disimpulkan bahwa ada pengaruh kecerdasan logis-matematis terhadap hasil belajar matematika artinya siswa yang memiliki kecerdasan logismatematis tinggi memiliki hasil belajar yang tinggi begitu juga sebaliknya.

Penjelasan berdasarkan penemuan tersebut yaitu: kecerdasan logis matematis merupakan salah satu kecerdasan dari delapan kecerdasan yangdikemukakan dalamteori multiple intelligence (kecerdasan majemuk). Kecerdasan majemuk ini memberikan pengaruh manusia dalam prosesmendapatkan pengetahuan. Melaluikecerdasan majemuk, manusia mampuberfikir dan mengembangkan pengetahuannya serta dapat berinteraksi dengan lingkungan sekitarnya.

Kecerdasan logis matematis merupakankecerdasan manusia dalam mengolah angka, berhitung, memecahkanmasalah, berfikir logis, berfikir 
matematis dan kemampuanmengidentifikasi pola hubungan tertentu.Beberapa indikator kecerdasanlogis matematis inilah yang membantu manusia mencapai keberhasilandalam pembelajaran.Kecerdasan logis matematis ini erat kaitannya denganpelajaran matematika. Jika kecerdasan logis matematis manusia baik makakemampuan dalam memahami materi pelajaran matematika juga lebihmaksimal sehingga diharapkan hasil belajar matematika juga akanmaksimal. Purwanto mengemukakan bahwa "cepat tidaknya danterpecahkan atau tidaknya suatu masalah tergantung kepada kemampuaninteligensinya". ${ }^{31}$

Dengan kemampuan inteligensi yang dimiliki seorangsiswa, maka memudahkannya dalam memahami pelajaran.Denganpemahaman dan penguasaan materi yang dimilikinya, seorang siswa dapatmengerjakan soal dengan kemampuannya tanpa kesulitan, sehingga siswatersebut mampu mendapatkan hasil belajar yang optimal.

\section{KESIMPULAN}

Berdasarkan hasil penelitian ini maka dapat ditarik kesimpulan yaitu ada pengaruh yang signifikan antara variabel kecerdasan Logis-Matematis dengan hasil belajar matematika kelas VII MTsN 2 Padangsidimpuan. Artinya kecerdasan Logis-matematis yang tinggi akan memudahkan siswa dalam belajar dan memahami matematika sehingga siswa cepat menyelesaikan permasalahan yang berkaitan dengan matematika. Hal ini ditunjukkan dengan hipotesis statistik yaitu menggunakan uji t. berdasarkan uji Hipotesis diperoleh uji thitung sebesar 17,137lebih besar dari $t$ tabel sebesar 1,98(17,137 > 1,98) sehingga diambil kesimpulan bahwa $\mathrm{H}_{0}$ di tolak karena $\mathrm{t}_{\text {hitung }}>\mathrm{t}$ tabel dan besarnya signifikan $(a) 5 \%$.

\section{DAFTAR PUSTAKA}

Abdurrahman, Mulyono, Anak Berkesulitan Belajar, Jakarta: PT Rineka Cipta, 2012.

B. Uno, Hamzah, Model Pembelajaran, Jakarta: Bumi Aksara, 2008. dan Masri Kuadrat, Mengelola Kecerdasan dalam Pembelajaran: Sebuah Konsep Pembelajaran Berbasis Kecerdasan, Jakarta: PT Bumi Aksara, 2009.

Chatib, Munif, Gurunya Manusia, Bandung: Kaifa, 2014.

Noruzi, Mohammad Reza, "The Enigma of Howard Gardner's Multiple Intelligences Theory in the Area of Organizational Effectiveness", International Journal of Business and Management, Vol. 5, No. 5, May 2010 . hlm. 52.

${ }^{31}$ Ngalim Purwanto, Psikologi Pendidikan (Bandung: PT Remaja Rosdakarya, 2011), 
Purwanto, Evaluasi Hasil Belajar, Yogyakarta: Pustaka Belajar, 2014.

Purwanto, Ngalim, Prinsip-Prinsip dan Teknik Evaluasi Pengajaran, Bandung: PT Remaja Rosdakarya, 2001.

Santrock, John W, Perkembangan Anak, Indonesia: Erlangga, 2007.

Slameto, Belajar dan Faktor-faktor yang Mempengaruhinya, Jakarta: PT Rineka Cipta, 2010.

Subini, Nini, Mengatasi Kesulitan Belajar Pada Anak, Jogjakarta: Javalitera, 2011.

Sudjana, Nana, Penilaian Hasil Proses Belajar Mengajar, Bandung: PT Remaja Rosdakarya, 2001.

Sukmadinata, Nana Syaodih, Landasan Psikologi Proses Pendidikan, Bandung: Ramaja Rosdakarya, 2004.

Tirtarahardja, Umar, Pengantar Pendidikan, Jakarta: PT Rineka Cipta, 2005.

Trisna Jayantika, dkk. "Kontribusi bakat numerik, kecerdasan spasial, dan kecerdasan logis matematis terhadap prestasi belajar matematika siswa SD Negeri di Kabupaten Buleleng" dalam Journal Program Pascasarjana Universitas Pendidikan Ganesha Program Studi Matematika, Volume 2, tahun 2013.

Undang-undang RI nomor 20 tahun 2003, Tentang Sistem Pendidikan Nasional 2003, Jakarta: Redaksi Sinar Grafika, 2009.

Usman, Moh. Uzer, Menjadi Guru Professional, Bandung: PT Remaja Rosdakarya, 2011.

Wijaya, Cece, Pendidikan Remedial, Bandung: Remaja Rosdakarya, 1996.

Yusuf, Syamsu dan Juntika Nurihsan, Landasan Bimbingan dan Konseling, Bandung: PT Remaja Rosdakarya, 2012.

Zahro', Anissatuz, “Pengaruh Kecerdasan Logis-Matematis terhadap Hasil Belajar Matematika siswa kelas VIII MTS ASWAJA Tunggangri” Skripsi, IAIN Tulungagung, 2015. 